\title{
Adult Pineal Parenchymal Cell Neoplasm
}

National Cancer Institute

\section{Source}

National Cancer Institute. Adult Pineal Parenchymal Cell Neoplasm. NCI Thesaurus. Code C8273.

A pineal parenchymal cell neoplasm (pineocytoma or pineoblastoma) occurring in adults. 